УДК 621.762

Кузьмов А. В. Штерн М. Б. Кіркова О. Г.

\title{
ОСОБЛИВОСТІ ОТРИМАННЯ ВИДОВЖЕНИХ ПОРОШКОВИХ ЗАГОТОВОК МЕТОДОМ ПРЕСУВАННЯ ІЗ ОБЕРТАННЯМ ПУАНСОНА
}

Отримання виробів методом порошкової металургії як правило здійснюється в дві стадії формування порошкової заготовки і консолідація цієї заготовки шляхом спікання. Традиційно найбільше поширення при формуванні порошкових заготовок набули схеми пресування в замкнених нерухомих прес-формах, тобто схеми одновісного деформування. Не дивлячись на значну кількість робіт в галузі холодного пресування порошків, проблема зниження енергетичних та силових витрат при пресуванні залишається актуальною навіть для простих схем ущільнення. 3 іншого боку відомо, що наявність додаткових зсувних компонент деформації певною мірою зменшує робочий тиск пресування $[1,2]$. У якості одного зі шляхів інтенсифікації зсувних деформацій в ході пресування є обертання матриць або пуансонів.

У той же час застосування схем деформування, що забезпечують наявність зсувних деформацій, набуває певного поширення при обробці тиском компактних матеріалів. При цьому, поряд 3 традиційними технологіями обробки металів тиском, існують методи обробки, основною метою яких є накопичення деформацій в заготовках, а не зміна їх форми. До таких методів належать гвинтова екструзія [3], рівноканальна кутова екструзія $[4,5]$, кручення під тиском $[4,6]$ та інші. В результаті використання подібних технологічних процесів можна отримати ультра дрібнозернисту структуру оброблюваного матеріалу, який набуває при цьому якісно нових властивостей.

Останнім часом ведуться активні дослідження з використання цих технологій для обробки порошкових заготовок $[7,8,9]$. Наявність зсувних деформацій призводить до сприятливої орієнтації металевих зерен, неметалевих включень і пор, появи текстури. Важливим завданням при цьому є можливість знизити енергосилові параметри процесу i, в результаті, підвищити стійкість деформуючого інструменту.

Слід зазначити, що теорія пластичності стисливих матеріалів прогнозує зменшення тиску пресування при миттєвій появі зсувних деформацій [1]. Проте, зазначений ефект фіксується лише на початку процесу. Подальше зниження прикладеного тиску є справедливим лише для тих випадків, коли матеріал порошку є ідеально пластичним. Протилежна картина спостерігається ході тривалого навантаження, коли наявність додаткових зсувних деформацій викликає підвищення деформаційного зміцнення внаслідок накопиченої деформації. Це призводить до протилежного ефекту - збільшення тиску пресування. Тому питання про доцільність застосування нестандартних схем пресування порошків зі зсувними деформаціями, крім аналізу доцільності ускладнення технологічного обладнання, потребує також дослідження впливу деформаційного зміцнення.

Авторами на основі розв'язку в аналітичному вигляді було досліджено на предмет доцільності з точки зору зменшення тиску пресування ідеалізовані схеми осьового [10] та радіального [11] пресування трубчатих заготовок з порошків при обертанні одна відносно одної зовнішньої та внутрішньої стінок прес-форми. Остання з цих двох схем близька до схеми SPD «highpressure tube twisting» запропонованій в роботі [12]. Проте у випадку повороту пуансона при ущільненні в нерухомій жорсткій матриці або вільній осадці (кручення під тиском), напружено деформований стан в заготовці є більш складним і його на думку авторів доцільніше досліджувати методами чисельного моделювання. Досить грунтовне дослідження кручення під тиском (high pressure torsion - НРТ) для малопористих попередньо спресованих порошкових заготовок проведено в роботі [13] .

Подібне дослідження проводилося у роботі [2], в якій схема 3 обертанням пуансона при пресуванні в закритій прес-формі досліджувалась шляхом обчислювального моделювання 
методом скінчених елементів. В цій роботі було розглянуто декілька конкретних випадків кінематичної схеми та реологічних параметрів матеріалу. Проте рекомендацій як в загальному випадку оцінювати доцільність схеми з точки зору зменшення робочого тиску дано не було.

Метою роботі поглиблений аналіз процесу пресування із обертанням, зокрема 3 врахуванням різних умов зчеплення між заготовкою та інструментом та можливості локалізації пластичної течії та втрати стійкості деформування.

Для проведення обчислювального моделювання використовувався метод скінчених елементів (MCE). Задача обчислювалась у програмному пакеті DEFORM. На рис. 1 зображено схему пресування циліндричної порошкової заготовки. В якості граничних умов при дослідженні впливу висоти заготовки та швидкості обертання пуансона на зменшення тиску пресування бралося повне зчеплення між заготовкою і пуансоном та між заготовкою і нижньою стінкою матриці, а також відсутність тертя (тобто вільне проковзування) між заготовкою і бічними стінками матриці. Для того щоб побачити вплив деформаційного зміцнення на очікуване зменшення тиску пресування, комп'ютерне моделювання здійснювалось для двох різних матеріалів твердої фази порошку AISI 5135H COLD (що $є$ аналогом конструкційної легованої сталі 40X) як для слабозміцнюваного, та AISI-316L COLD - нержавіюча сталь в якості сильнозміцнюваного.

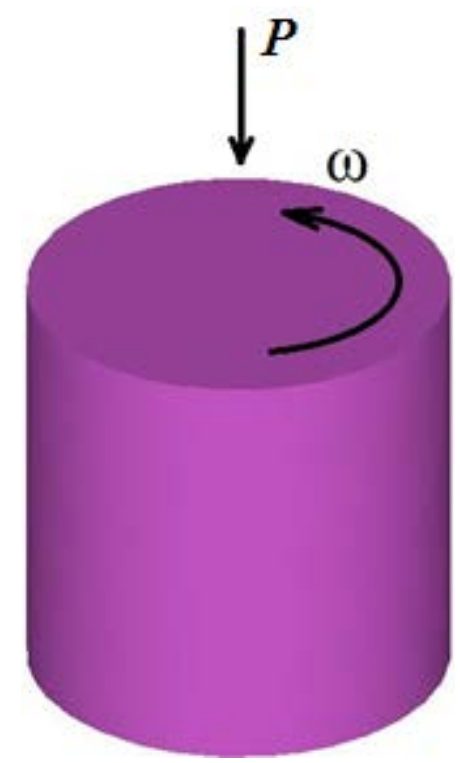

Рис. 1. Схема пресування пористого зразка

Відомо, що в ідеалізованому випадку пресування в закритій циліндричній прес-формі за вільного проковзування між порошком та прес-інструментом буде спостерігатися однорідний напружено-деформований стан. А саме одновісна деформація, для якої єдиною ненульовою компонентою тензора швидкостей деформацій буде $e_{z z}$ (де вісь z циліндричної системи координат напрямлена протилежно напряму руху пуансона). У випадку, коли тангенціальна швидкість $V_{z}$ передається від пуансона заготовці, навіть за відсутності тертя між зразком і бічними стінками матриці, на відміну від звичайної схеми пресування, буде спостерігатися неоднорідний напружено-деформований стан.

За таких граничних умов, кінематика схеми, внаслідок нечутливості зусиль при пластичній деформації до абсолютної величини швидкості, буде описуватись двома безрозмірними параметрами: $K=\frac{\varpi R}{2 V_{z}^{0}}$ (де $V_{z}^{0}$ та $\varpi-$ поступальна та кутова швидкість пуансона відповідно), та відношенням висоти заготовки до радіуса $\frac{H}{R}$. Тобто за співпадіння цих двох 
параметрів картина напружено-деформованого стану в об'ємі зразка теж буде співпадати. Зауважимо, що параметр $K$ можна інтерпретувати, також, як певну осереднену за об'ємом міру відношення зсувної деформації до стискаючої $\frac{e_{z \phi}}{e_{z z}}$.

Оскільки в нашому випадку форма заготовки задається тільки відношенням іiї висоти до діаметра, то в першу чергу буде досліджено вплив цих двох параметрів: відношення зсувної деформації до стискаючої - $K$ та відношення розмірів заготовки $\frac{H}{R}$ на процес пресування.

Відповідно при дослідженні впливу тертя між пуансоном та зразком між матрицею та зразком замість ідеального зчеплення або повного проковзування брались умови контактної взаємодії з певним коефіцієнтом тертя.

Вплив висоти заготовки та швидкості обертання пуансона на зменшення тиску пресування. Як видно на рис. 2, на якому зображено вплив відношення зсувної деформації до стискаючої на зусилля пресування пористого зразка із сталі $40 \mathrm{X}$, при $H=0.5 R$ робочий тиск монотонно спадає з ростом $K$, а при $K=4$ досягається двократне зменшення робочого тиску.

А при більших початкових висотах заготовки доцільність обертання пуансона для зменшення тиску пресування значно зменшувалась, при цьому для значень $K>1$ може спостерігатися зростання зусиль пресування, а для випадку $H=4 R$ при $K>2$ робочий тиск навіть більший, ніж за звичайної схеми без обертання пуансона. Слід відмітити, що при $K=1$ для всіх висот заготовки робочий тиск зменшується. Але для випадків $H>0.5 R$ внаслідок обертання пуансона спадання тиску пресування не перевищує 30 \%.

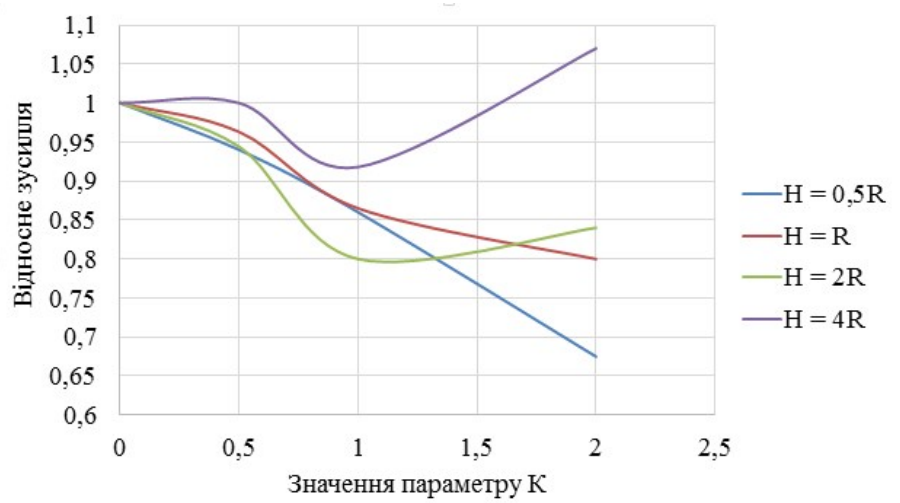

Рис. 2. Вплив параметру $K$ на зусилля пресування пористого зразка (сталь 40X)

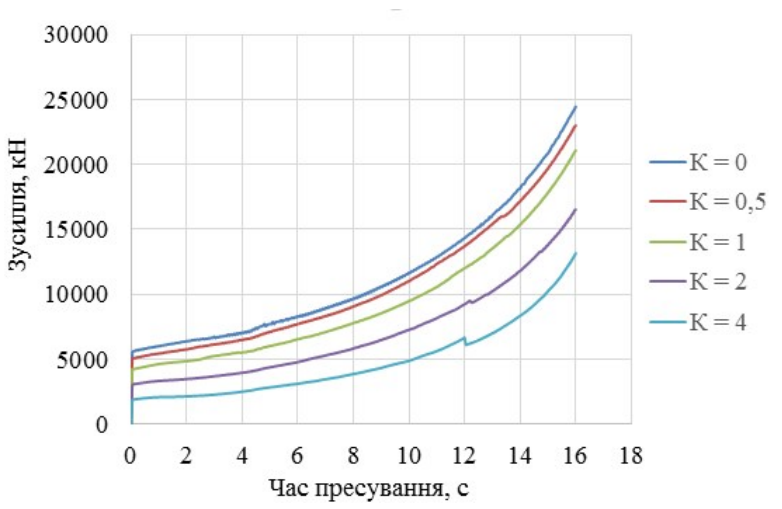

Рис. 3. Графік залежності зусилля пресування від часу із впливом параметру $K$ з висотою заготовки $H=0.5 R$ (сталь $40 \mathrm{X})$

Як видно із рис. 3 для випадку $H=0.5 R$ навіть при ущільненні пресовки до відносної густини 0.9 спостерігається значне зменшення тиску пресування, а на початку пресування за відносної густини 0.6 для випадку $K=4$ обертання пуансона призводить до практично трикратного зменшення тиску.

Втрата доцільності обертання пуансона для більш-менш високих, а не таблеткоподібних, заготовок пов'язана з явищем втрати стійкості деформування і виникненням зон локалізації пластичної течії.

Для випадку таблеткоподібної заготовки тангенціальна швидкість рівномірно передається від пуансона всій заготовці (рис. 4). Це видно з того, що абсолютна величина швидкості суттєво залежить від радіальної координати (тобто віддаленості точки від осі симетрії, а не тільки від координати по висоті), як це має місце за звичайної схеми пресування без обертання пуансону. 
У випадку не таблеткоподібної заготовки тангенціальна швидкість $V_{\varphi}$ або практично не передається від пуансона до заготовки (рис. 5), або передається вкрай нерівномірно $з$ локалізацією пластичної течії (рис. 6 та 7).
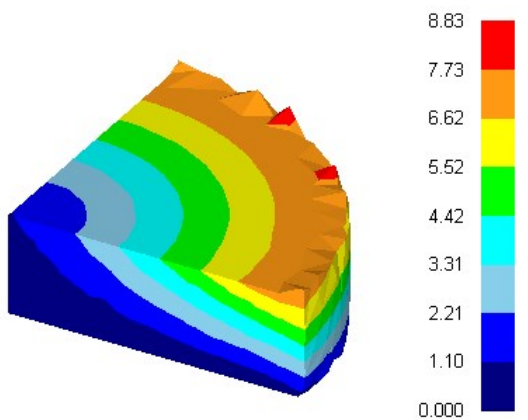

Рис. 4. Лінії рівня абсолютної швидкості при $H=0.5 R$ (сталь 40X)
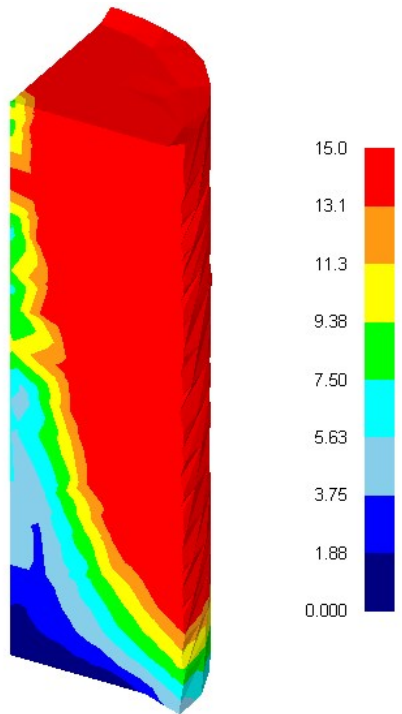

Рис. 6. Локалізація деформації за висоти заготовки $H=4 R, K=4$ (сталь $40 \mathrm{X}$ )

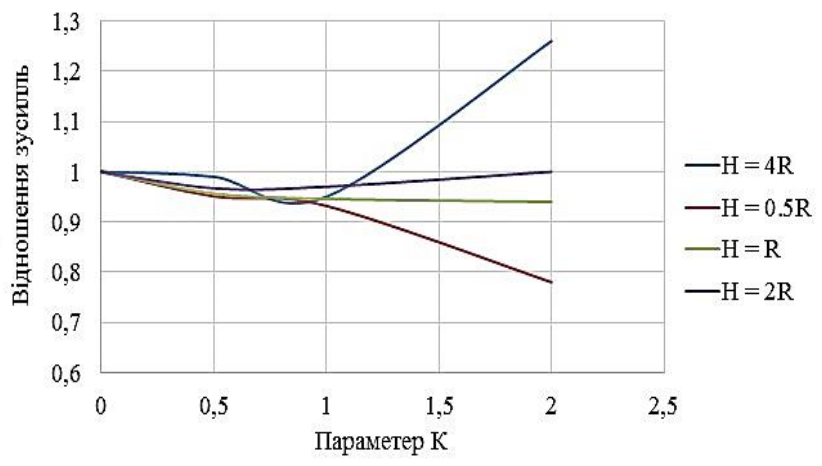

Рис. 8. Вплив параметру $K$ на зусилля пресування пористого зразка (нерж. сталь)
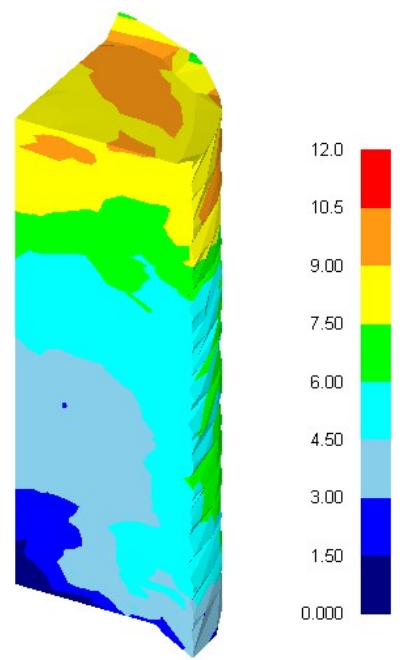

Рис. 5. Лінії рівня абсолютної швидкості при $H=4 R$ (сталь 40X).
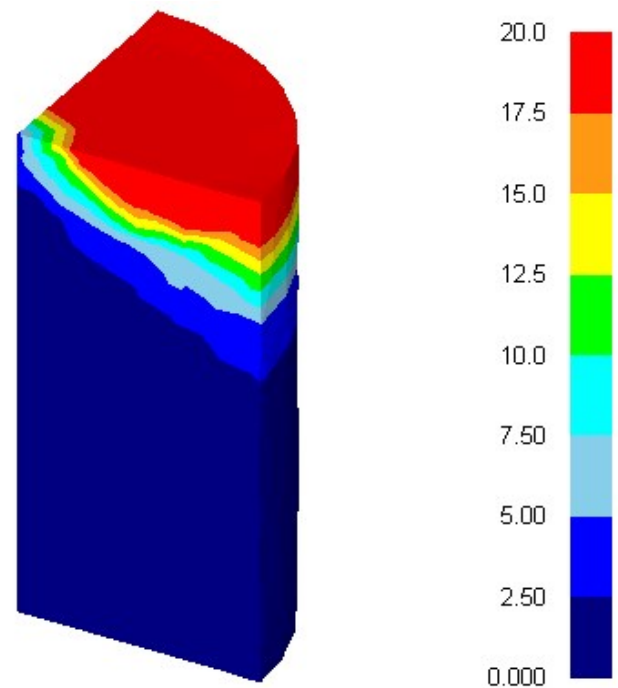

Рис. 7. Локалізація деформації за висоти заготовки $H=2 R, K=1$ (сталь 40X)

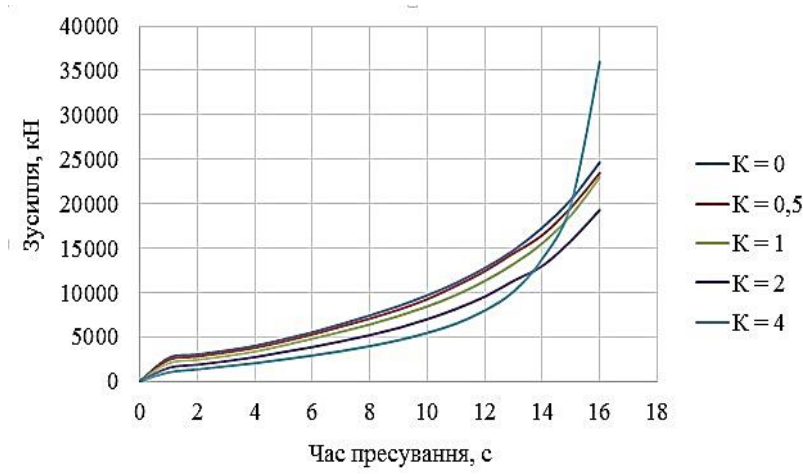

Рис. 9. Графік залежності зусилля пресування від часу при впливі параметра $K$ з висотою заготовки $H=0.5 R$ (нерж. сталь) 
У випадку матеріалу з великим деформаційним зміцненням у цілому спостерігається та сама картина (рис. 8-13), за якої обертати пуансон для зменшення робочого тиску доцільно тільки для випадку таблеткоподібної заготовки $H=0.5 R$. Хоча слід відмітити, що внаслідок посилення деформаційного зміцнення матеріалу виграш у падінні тиску пресування навіть для випадку $H=0.5 R$ не перевищує $30 \%$ (рис. 8).

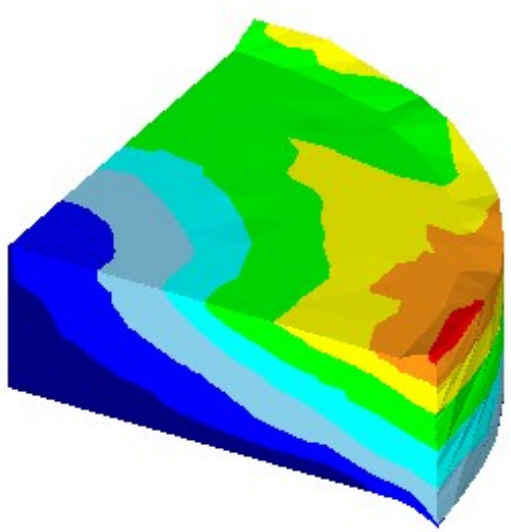

Рис. 10. Лінії рівня швидкості при $H=0.5 R$ (нерж. сталь)

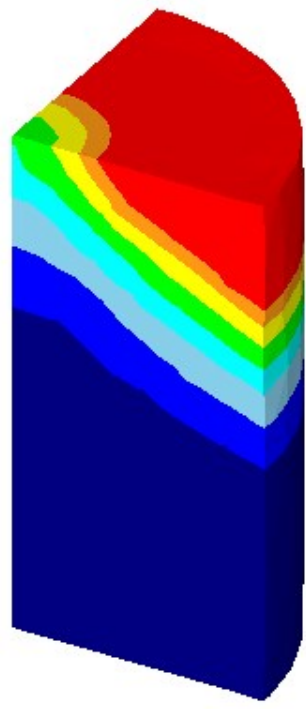

Рис. 12. Локалізація в пористій заготовці $H=2 R, K=2$ (нерж. сталь)

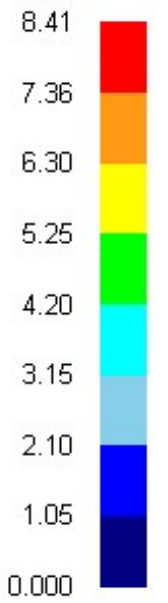

абсолютної

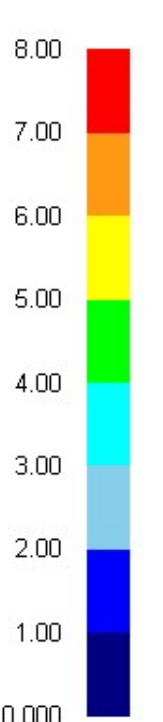

деформації

Вилив зчеплення між пуансоном та заготовкою на процес ущільнення. Оскільки повне зчеплення між заготовкою та пуансоном $є$ певною ідеалізацією хотілося б дослідити вплив коефіцієнта тертя між заготовкою та пуансоном на тиск пресування та інші параметри процесу. В попередньому підрозділі було встановлено, що навіть при повному зчепленні між заготовкою та пуансоном і нижньою стінкою матриці, схему з обертанням пуансона доцільно застосовувати тільки для невисоких заготовок. Тому комп'ютерне моделювання здійснюватиметься тільки для заготовок висотою $\mathrm{H}=0.5 \mathrm{R}$ i $\mathrm{H}=\mathrm{R}$. В якості граничних умов було покладено коефіцієнт тертя між заготовкою та бічними стінками матриці рівним 0.08, а коефіцієнт тертя між заготовкою та пуансоном і нижньою стінкою матриці варіювався в діапазоні від 0.08 до 0.7. Матеріалом твердої фази була нержавіюча сталь AISI - 316L COLD. 


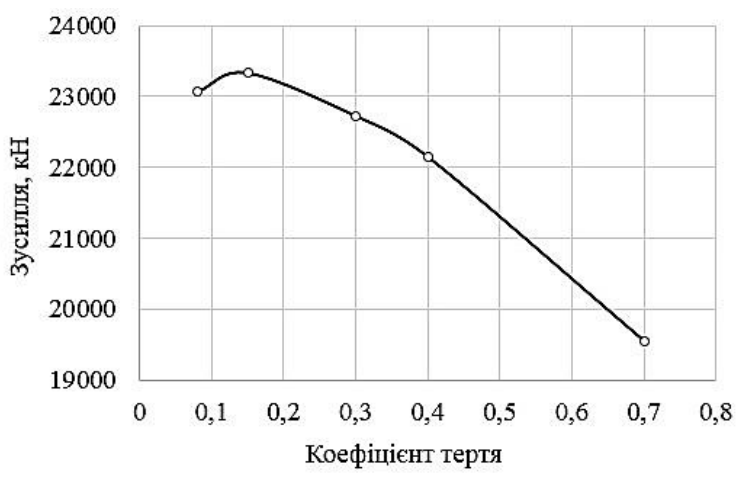

Рис. 14. Графік залежності зусилля пресування від коефіцієнта тертя на пуансоні з висотою заготовки $\mathrm{H}=0.5 \mathrm{R}$
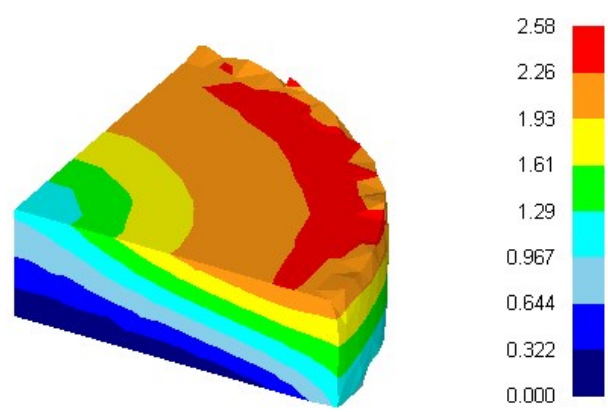

Рис. 16. Лінії рівня абсолютної швидкості при висоті заготовки $\mathrm{H}=0.5 \mathrm{R}$ коефіцієнт тертя на пуансоні 0,7 та на матриці 0,08

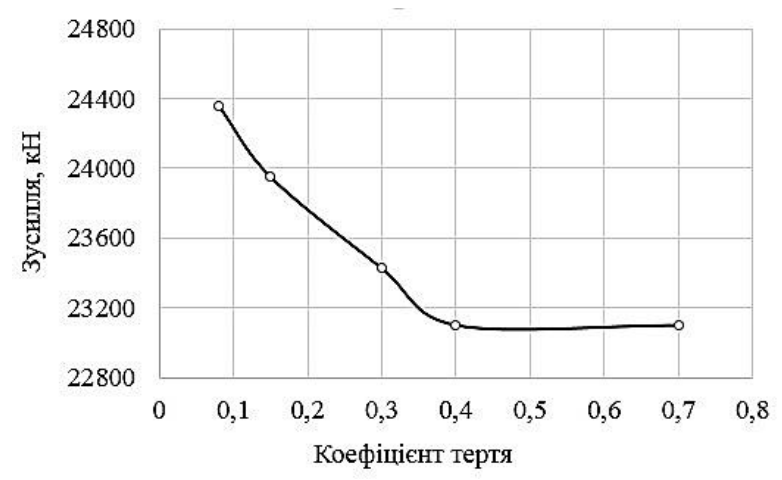

Рис. 15. Графік залежності зусилля пресування від коефіцієнта тертя на пуансоні з висотою заготовки $\mathrm{H}=\mathrm{R}$
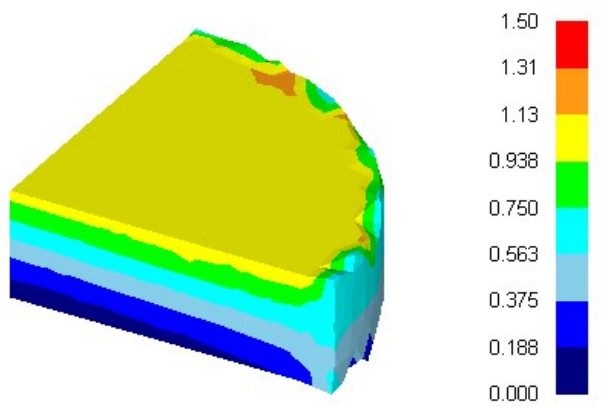

Рис. 17. Лінії рівня абсолютної швидкості при висоті заготовки $\mathrm{H}=0.5 \mathrm{R}$ коефіцієнт тертя на пуансоні та на матриці 0,08

Виявилось (рис. 14), що для випадку $\mathrm{H}=0.5 \mathrm{R}$ збільшення коефіцієнт тертя між заготовкою та пуансоном викликає пропорційне зменшення робочого тиску. При малому коефіцієнті тертя між заготовкою та пуансоном (рис.17) абсолютна величина швидкості залежить тільки від координати по висоті як це має місце при звичайній схемі пресуваня без обертання пуансона, а при коефіцієнті тертя 0.7 (рис. 16) тангенційна швидкість $V_{\varphi}$ досить рівномірно передається від пуансона до всієї заготовці.
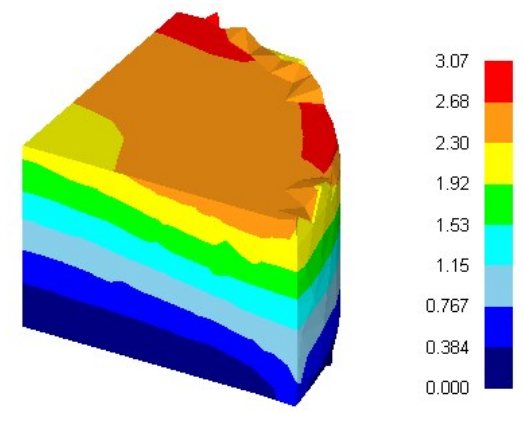

Рис. 18. Лінії рівня абсолютної швидкості при висоті заготовки $\mathrm{H}=\mathrm{R}$ коефіці$\epsilon$ те тертя на пуансоні 0,7 та на матриці 0,08

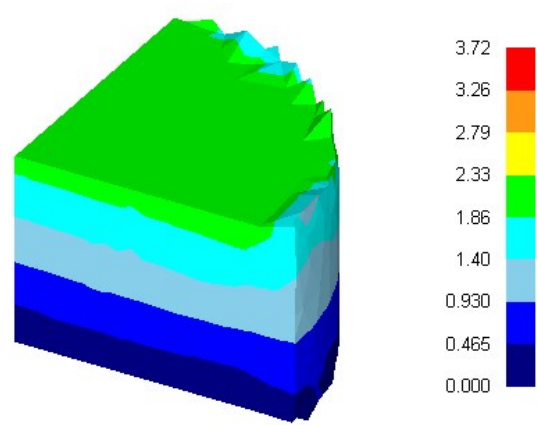

Рис. 19. Лінії рівня абсолютної швидкості при висоті заготовки $\mathrm{H}=\mathrm{R}$ коефіцієнт тертя на пуансоні та на матриці 0,08 
Для випадку $\mathrm{H}=\mathrm{R}$ зменшення робочого тиску пропорційне до збільшення коефіцієнта тертя між заготовкою та пуансоном спостерігається тільки до величини коефіцієнта тертя 0.4, подальше збільшення коефіцієнта тертя майже зовсім не вливає на тиск пресування (рис. 15). Це викликане тим, що на відміну від випадку $\mathrm{H}=0.5 \mathrm{R}$ при досягненні коефіцієнтом тертя, а отже і крутним моментом на заготовці, певної межі відбувається втрата стійкості деформування та починають з'являтися зони локалізації пластичної течії.

При малому коефіцієнті тертя між заготовкою та пуансоном абсолютна величина швидкості залежить тільки від координати по висоті (рис. 19), а при коефіцієнті тертя 0.7 тангенційна швидкість передається від пуансона до заготовки (рис. 18).

\section{ВИСНОВКИ}

В ході обчислювального моделювання методом скінчених елементів впливу обертання пуансона на робочий тиск під час пресування циліндричних заготовок встановлено, що доцільність такої схеми для простих циліндричних заготовок залежить в першу чергу від відношення ії висоти до діаметра. Обертання пуансона доцільно здійснювати для невисоких таблеткоподібних заготовок, для яких початкова висота не перевищує радіус $H<R$. У випадку високих заготовок $H>2 R$ спостерігається втрата стійкості деформування та поява зон локалізації пластичної течії, що у випадках швидкостей обертання пуансона $K>1$ як правило призводить до збільшення тиску пресування у порівнянні зі стандартною схемою у відсутності обертання пуансона.

Ступінь деформаційного зміцнення матеріалу каркасу порошкового матеріалу також впливає на тиск пресування. Для більш зміцнюваного матеріалу нержавіючої сталі знижується ефект зменшення тиску пресування у порівнянні із конструкційною легованою сталлю 40X. А при значних швидкостях обертання пуансона $\mathrm{K}>4$ для нержавіючої сталі спостерігається зворотній ефект збільшення робочого тиску у порівнянні із звичайним пресуванням без обертання пуансона навіть для таблеткоподібної заготовки $H=0.5 R$.

Також було показано доцільність досягати різними засобами покращення зчеплення між пуансоном та заготовкою та водночас зменшувати зчеплення між заготовкою і бічними стінками матриці для запропонованої схеми пресування.

\section{СПИСОК ВИКОРИСТАНОЇ ЛІТЕРАТУРИ}

1. Штерн М. Б. Развитие теории прессования и пластического деформирования порошковых материалов. Порошковая металлургия. 1992. 9. С. 12-24.

2. Михайлов О. В., Штерн М. Б. Вплив крутіння пористих заготовок на їх ущільнення в закритому штампі. Математичні моделі $i$ обчислювальний експеримент в матеріалознавстві. Київ: ІІМ ім. І. М. Францевича НАН України. 2013. 15. С. 81-85

3. Бейгельзимер Я. Е., Варюхин В. Н., Орлов Д. В., Сынков С. Г. Винтовая экструзия - процесс накопления деформации. Донецк: ТЕАН. 2003. 85 с.

4. Валиев Р. 3., Александров И. В. Наноструктурные материалы, полученные интенсивной пластической деформацией. Москва: Логос. 2000. 271 с.

5. Сегал В. М., Резников В. И., Копылов В. И., Павлик Д. А., Малышев В. Ф. Процессы пластического структурообразования металлов. Минск: Навука и тэхника. 1994. 232 с.

6. Бриджмен П. В. Исследование больших пластических деформаций и разрыва. Москва: Изд-во иностранной литературы. 1955. 444 с.

7. Varyukhin V. N., Beygelsimer Y. Y., Synkov S.G. et al. Consolidation of amorphous Al86Ni6Go2Gd6 melt spun ribbons by twist extrusion. Material Science Forum. 2006. 503-504, pp. 699-704.

8. Xiang S., Matsuki K., Tahatsuju N., Tokizawa M., et al. Microstructure and mechanical properties of PM $2024 \mathrm{Al}-3 \mathrm{Fe}-5 \mathrm{Ni}$ alloy consolidated by a new process, equal channel angular pressing. Journal of Materials Science Letters. 1997. 16. pp. 1725-1727.

9. Xia K., Wu X. Back pressure equal channel angular consolidation of pure Al particles. Scripta Materialia. 2005. 53, pp. 1225-1229.

10. Кузьмов А. В., Штерн М. Б. Анализ влияния вращения пресс-инструмента на уменьшение рабочего давления при холодном прессовании порошков металлов. Математичні моделі і обчислювальний експеримент матеріалознавстві. Київ: ІПМ ім. І. М. Францевича НАН України. 2018. 20. С. 98-103. 
11. Кузьмов А. В., Штерн М. Б. Уменьшение давления путем вращения пресс-инструмента при радиальном прессовании трубчатых заготовок из порошков металлов. Обработка материалов давлением. Краматорск: ДГМА. 2019. 2(49). С. 143-149.

12. Tóth L.S., Arzaghi M., Fundenberger J. J., Beausir B. et al. Severe plastic deformation of metals by highpressure tube twisting. Scripta Materialia. 2009. 60, pp. 175-177.

13. Kulagin R., Zhao Y., Beygelzimer Y., Toth Laszlo S., Shtern M. Modeling strain and density distributions during high-pressure torsion of pre-compacted powder materials. Materials Research Letters. 2017. 5. 3, pp. $179-186$.

\section{REFERENCES}

1. Stern M.B. Development of the theory of pressing and plastic deformation of powder materials. Powder Metallurgy. 1992. 9, pp. 12-24. (in Russian).

2. Mikhailov O.V., Stern M.B. Intrusion of porous workpieces at the openings in closed stamp. Mathematical models and descriptive experiment in materials. Kyiv: IPM named I.M.Frantsevich of NAS Ukraine. 2013. 15, pp. 81-85. (in Ukrainian).

3. Beigelzimer Y.E., Varyukhin V.N., Orlov D.V., Synkov S.G. Screw extrusion is the process of strain accumulation. Donetsk: TEAN. 2003. 85 p. (in Russian).

4. Valiev R.Z., Aleksandrov I.V. Nanostructured materials obtained by intensiv plastic deformation. Moscow: Logos. 2000. 271 p. (in Russian).

5. Segal V.M., Reznikov V.I., Kopylov V.I., Pavlik D.A., Malyshev V.F. Processes of plastic structure formation of metals. Minsk: Science and technology. 1994. 232 p. (in Russian).

6. Bridgman P.V. Research of large plastic deformations and rupture. Moscow: Publishing house of foreign literature. 1955. 444 p. (in Russian).

7. Varyukhin V.N., Beygelsimer Y.Y., Synkov S.G., et al. Consolidation of amorphous Al86Ni6Go2Gd6 melt spun ribbons by twist extrusion. Material Science Forum. 2006. 503-504, pp. 699-704.

8. Xiang S., Matsuki K., Tahatsuju N., Tokizawa M., et al. Microstructure and mechanical properties of PM $2024 \mathrm{Al}-3 \mathrm{Fe}-5 \mathrm{Ni}$ alloy consolidated by a new process, equal channel angular pressing. Journal of Materials Science Letters. 1997. 16, pp. 1725-1727.

9. Xia K., Wu X. Back pressure equal channel angular consolidation of pure Al particles. Scripta Materialia. 2005. 53, pp. 1225-1229.

10. Kuzmov A.V., Shtern M.B. Analysis of the influence of the rotation of the press tool on the decrease in working pressure during cold pressing of metal powders. Mathematical models and descriptive experiment in materials. Kyiv: IPM named I.M.Frantsevich of NAS Ukraine. 2018. 20, pp. 98-103. (in Ukrainian).

11. Kuzmov A. V., Shtern M. B. Reducing pressure by rotating the press tool during radial pressing of tubular billets of metal powders. Materials working by pressure. 2019. 2 (49), pp (in Russian).

12. Tóth L.S., Arzaghi M., Fundenberger J.J., Beausir B., et al. Severe plastic deformation of metals by highpressure tube twisting. Scripta Materialia. 2009. 60, pp. 175-177.

13. Kulagin R., Zhao Y., Beygelzimer Y., Toth Laszlo S., Shtern M. Modeling strain and density distributions during high-pressure torsion of pre-compacted powder materials. Materials Research Letters. 2017. 5. 3, pp. 179-186.

Кузьмов А. В. - ст. наук. співроб. ІПМ НАНУ, ст. викл. НТУУ «КПІ»;

Штерн М. Б. - нач. від. ІПМ НАНУ, проф. НТУУ «КПІ»;

Кіркова О.Г. - ст. наук. співроб. ІПМ НАНУ.

ІПМ НАНУ - Інститут проблем матеріалознавства ім. І. М. Францевича НАН України, м. Київ.

НТУУ «КПІ» - Національний технічний університет України «Київський політехнічний інститут імені Ігоря Сікорського», м. Київ.

E-mail: kavipms326@gmail.com 